Research Article

openठิaccess

\title{
Expression of Pediocin PA-1 in Escherichia coli
}

\author{
Nguyen Thi Cam Nhung ${ }^{1}$, Nguyen Hieu Nghia ${ }^{1}$, Dang Thi Phuong Thao ${ }^{1,2^{*}}$ \\ ${ }^{1}$ Department of Molecular and Environmental Biotechnology, Faculty of Biology and Biotechnology, University of \\ Science, Vietnam National University-Ho Chi Minh City, Ho Chi Minh City 70000, Vietnam \\ ${ }^{2}$ Laboratory of Molecular Biotechnology, University of Science, Vietnam National University-Ho Chi Minh City, Ho Chi \\ Minh City 70000, Vietnam
}

*Address for Correspondence: Dr. Dang Thi Phuong Thao, Head, Department of Molecular and Environmental Biotechnology, University of Science, Vietnam National University, Ho Chi Minh City, 227 Nguyen Van Cu Street, District 5, Ho Chi Minh City, Vietnam

E-mail: dtpthao@hcmus.edu.vn

Received: 22 Jun 2018/ Revised: 27 Sep 2019/ Accepted: 29 Nov 2019

\begin{abstract}
Background: Pediocinis an antimicrobial peptide, which strongly inhibits Listeria monocytogenes. Previous reports showed that pediocin remarkable and promising potential in the food preservation industry and pharmaceutical. Although pediocin had been expressed in some $E$. coli strains, the production of pediocin still need more study.

Methods: In this study, we present our results on expression recombinant pediocin as solble protein in $E$. coli. $\mathrm{N}$-terminus of the pediocin gene was incorporated into the NusA tag, coordinated with 6xHistidine.

Results: Active recombinant pediocin was successfully obtained and showed its strong antibacterial activity against $L$. monocytogenes ATCC.

Conclusion: The result will be opened a new door to produce recombinant pediocin and apply it.
\end{abstract}

Key-words: Antibacterial activity, E. coli expression, Pediocin, Listeria monocytogene, NusA tag

\section{INTRODUCTION}

Pediocin PA-1 is a class Ila bacteriocin which produced by Pediococcus acidilactici PAC1.0. ${ }^{[1,2]}$. Pediocin PA-1 has a wide antibacterial spectrum against Gram-positive bacterial sp. such as Lactobacilli, Leuconostoc, Brochothrix thermosphacta, Probionibacteria, Bacilli, Enterococci, Staphylococci, L. clostridia, $L$. monocytogenes, and $L$. innocua. Pediocin was commercialized as a food presevative for several types of foods, particularly, which have to be prevented from $L$. monocytogenes ${ }^{[3]}$. As nisin, pediocin is widely applied in food presevation, particularly, which is strictly prohibited from L. monocytogenes.

Previous studies reported that pediocin showed its effectiveness of preservation, several different kinds of

How to cite this article

Nhung NTC, Nghia NH, Thao DTP. Expression of Pediocin PA-1 in Escherichia coli. SSR Inst. Int. J. Life Sci., 2019; 5(6): 2442-2448.

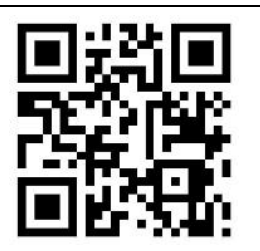

Access this article online https://iijls.com/ food such as sausage, milk, chicken meat, beef, salmon ${ }^{[4-}$ ${ }^{11]}$. Pediocin could be used directly as metabolite from Pediococcus, when the microorganism was added into sausage and milk ${ }^{[4,5]}$. Besides, purified pediocin was added into foods ${ }^{[7-10]}$. In the order hand, pediocin was also reported as anticancer activity on liver cell line A$549^{[12]}$. Recombinant pediocin had been produced from some different expression systems including $E$. coli. Halami, 2007, reported that recombinant pedicoin was successfully produced in inclusion bodies of E. coli BL21 (DE3). The recombinant pediocin was then refolded and purified to obtain its antibacterial activity on the $L$. monocytogenes $\mathrm{V} 7{ }^{[13]}$. Pediocin PA-1 was also expressed in E. coli M15 as fusion protein with His-tagged mouse dihydrofolate reductase (DHFR). The recombinant pediocin showed its antibacterial activity against $L$. plantarum NCDO $955^{[14]}$. In this study, we show our results on producing recombinant pediocin as soluble protein in E. coli BL21(DE3).

\section{MATERIALS AND METHODS}

The study was performed in the Laboratory of Molecular 
and Environmental Biotechnology, University of Science, VNU.HCM, Vietnam from 2016 to 2019.

Strains and Plasmid- DH5 $\alpha$ E. coli (F-, \$80lacZAM15, recA1, endA1, hsdR17 (rk-, mk+), phoA, supE44, $\lambda-$, thi-1, gyrA96, relA1), BL21(DE3) E. coli $\mathrm{F}^{-}$, ompT, hsdSB ( $\mathrm{rB}^{-}, \mathrm{mB}^{-}$ ), $g a l, d c m$ (DE3) and plasmid pET43.1a(+) were purchased from Invitrogen. Indicator bacteria were suported by Laboratory of Molecular and Environmental Biotechnology, University of Science, VNU.HCM, Vietnam.

E. coli strain was grown at $37^{\circ} \mathrm{C}$ in low salt Luria-Bertani (LB) broth ( $1 \%$ tryptone, $0.5 \%$ yeast extract, $0.5 \% \mathrm{NaCl}$ ). Plamsid carried E. Coli was grown on LB medium, which supplemented with ampicillin $(100 \mu \mathrm{g} / \mathrm{ml})$. Indicator strains were grown at $37^{\circ} \mathrm{C}$ in Tryptic Soy Broth (Tryptone $1.7 \%$, Peptone $0.3 \%$, D-glucose $0.25 \%, \mathrm{NaCl}$ $\left.0.5 \%, \mathrm{~K}_{2} \mathrm{HPO}_{4} 0.25 \%\right)$.

Construction of recombinant vector pET43.1a-ped- The construction of recombinant vector was designed following et al. ${ }^{[15]}$ with modification. Pediocin encoding gene was synthesized based on nucleotide sequence of pediocin gene in P. acidilactici PAC1.0. and amplified by PCR with set of primers (BamHI-ped: CGCGGATCCGATG ACGACGACAAGAAATATTATGGTAATGGTGTTACCTGTGGT AAACATAGC and Xhol-ped: CCGCTCGAGCGGTTAACATTT ATGATTACCCTGATGA CCACC). The Bam HI-Xhol-pediocin DNA fragment was then inserted into PET43.1a(+) vector by T4 ligase. The T4 ligation product was transformed into $\mathrm{DH} 5 \alpha \mathrm{E}$. coli. The recombinant vector was analyzed by PCR and sequencing.

Expression of NusA-his-pediocin fusion protein- The expression of recombinant pediocin was performed followed by Moon et al. [15] with modification. Recombinant plasmid pET43.1a-ped was transformed into BL21 (DE3) E. coli. TheBL21(DE3) E. coli transformed strain were induced by IPTG $0.8 \mathrm{mM}$ when the optical density reaches $0.6-0.8$ units $\left(\mathrm{OD}_{600}=0.6-0.8\right)$ then harvested by centrifugation at $5000 \mathrm{rpm}$ for 7 minutes after 2 hours further grown. The cell pellet after harvested was re-suspended in the binding buffer containing $\mathrm{Na}_{2} \mathrm{HPO}_{4} 50 \mathrm{mM}, \mathrm{NaCl} 300 \mathrm{mM}$, Imidazole $10 \mathrm{mM} \mathrm{pH} 7.4$ then sonicated using a homogenizer to disrupt the cells. To separate the precipitate and soluble fractions, the cell lysates then obtained by centrifugation at $13000 \mathrm{rpm}$ for 15 minutes. To determine the presence and location of fused-pediocin, 3 fractions: total, precipitate and soluble of was checked for the expression by SDS-PAGE and confirmed indirectly by Western blot with anti-his antibody (Invitrogen).

Pediocin purification by affinity chromatographyThepurification of recombinant pediocin was followed by Moon et al. ${ }^{[15]}$ with modification. Soluble fraction from $E$. coli lysate was filtered by $0.2 \mathrm{~mm}$ low-protein-binding membrane and $10 \mathrm{ml}$ of sample was applied to nickelNTA agarose resin, which was first equilibrated by $5 \mathrm{CV}$ binding buffer, followed by $15 \mathrm{CV}$ buffer $\mathrm{A}$ containing $\mathrm{Na}_{2} \mathrm{HPO}_{4} 50 \mathrm{mM}, \mathrm{NaCl} 300 \mathrm{mM}, \mathrm{pH} 7.4$ to wash the column. The NusA-his-pedioc infused pediocin was eluted by buffer B $\left(50 \mathrm{mM} \mathrm{NaH}_{2} \mathrm{PO}_{4}, 300 \mathrm{mM} \mathrm{NaCl}, 500\right.$ $\mathrm{mM}$ Imidazole $\mathrm{pH}$ 7.4). Eluted protein was analyzed by SDS-PAGE and Bradford assay.

\section{Antimicrobial assay on Tricine SDS-PAGE gel-} Antibacterial assay on tricine SDS-PAGE gene was applied as described by Bhunia et al. ${ }^{[16]}$. Two SDS-PAGE gels were run under the same condition, one was used for silver stained and the other was fixed with a solution containing $10 \%$ acetic acid and $20 \%$ isopropanol for 30 minutes, wash carefully with deionized water overnight. The gel was placed into a sterile petri dish and overlaid with $5 \mathrm{ml}$ soft TSB-agar medium containing indicator bacteria, which was prepared the same as in the agar diffusion test. The test plate was incubated at $37^{\circ} \mathrm{C}$ until the inhibition zone was observed.

\section{RESULTS}

Pediocin expression in E. coli- To express pediocin in the cytoplasm of the $E$. coli cells, we introduce pediocin encoding gene into pET43.1a vector (Fig. 1).

After cloning E. coli B/21 Dec3 strain was utilized to express pediocin. Since pET43.1a was designed to express the soluble heterologous protein in E. coli, the recombinant pediocin was obtained as a soluble protein in the cytoplasm (Fig. 2). Besides, N-terminus of the pediocin encoding gene (ped) was fused with $6 \mathrm{x}$ histidine, sequenced by NusA tag, thereby the NusA-hisPediocin fusion protein was detected by Wetern Blot with anti-his antibody. After the expression process, recombinant protein was obtained and introduced into SDS-PAGE analysis. The results showed that pediodin was expressed as NusA-his-pediocin fused protein with the molecular mass of more than $66 \mathrm{k} \mathrm{Da}$, confirmed by the Western blot with anti-his-antibody (Fig. 2). 


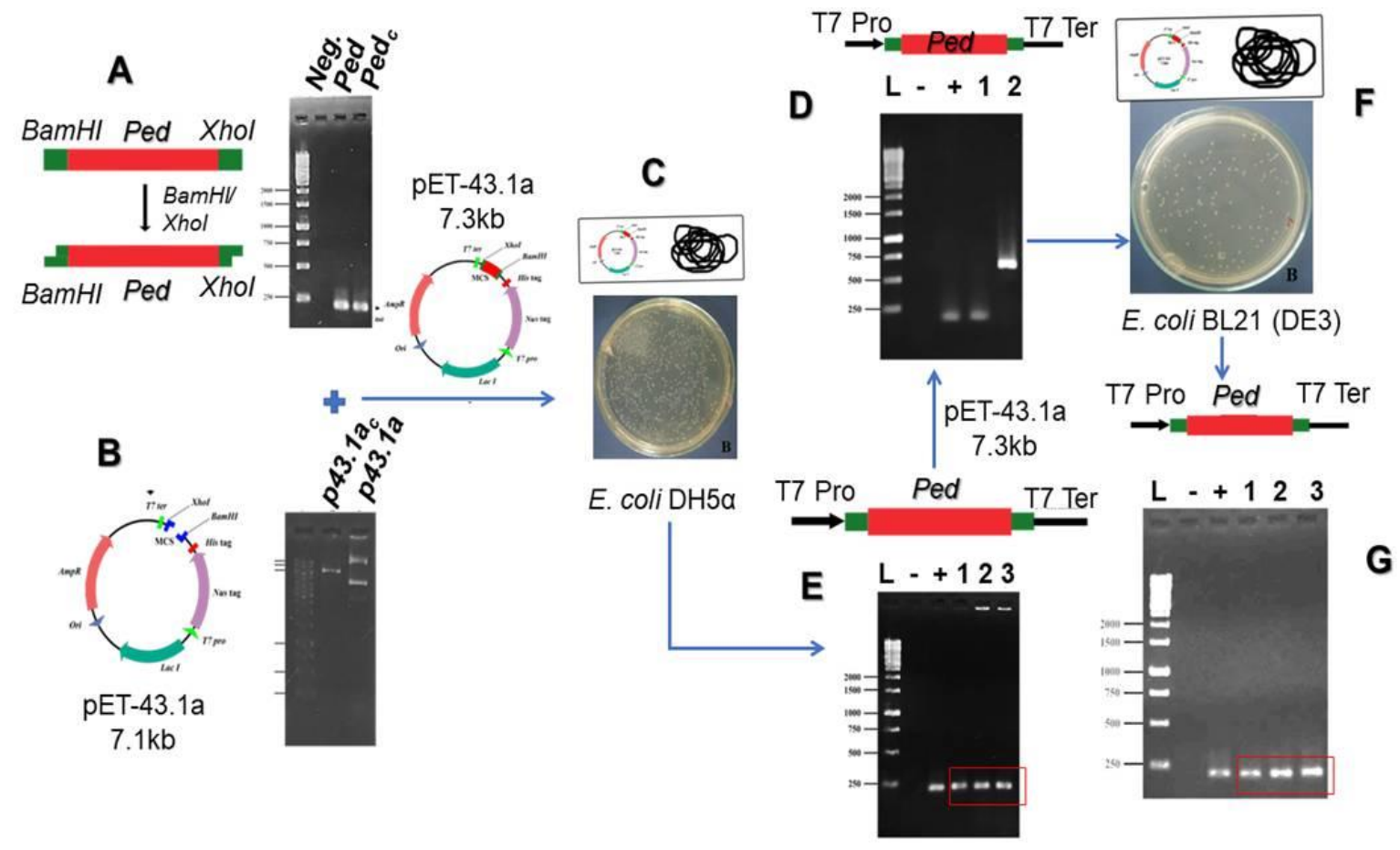

Fig. 1: Construction of peidocin expression vector in E. coli

A: Obtaining pediocin gene with BamHI/Xhol cohesive ends

B: Obatining pET43.1a with BamHI/Xhol cohesive ends

C: Introduction of recombinant vector into $\mathrm{DH} 5 \alpha \mathrm{E}$. coli

D-G: Confirmation of pediocin expression vector and recombinant vector carried BL21 Dec. PCR
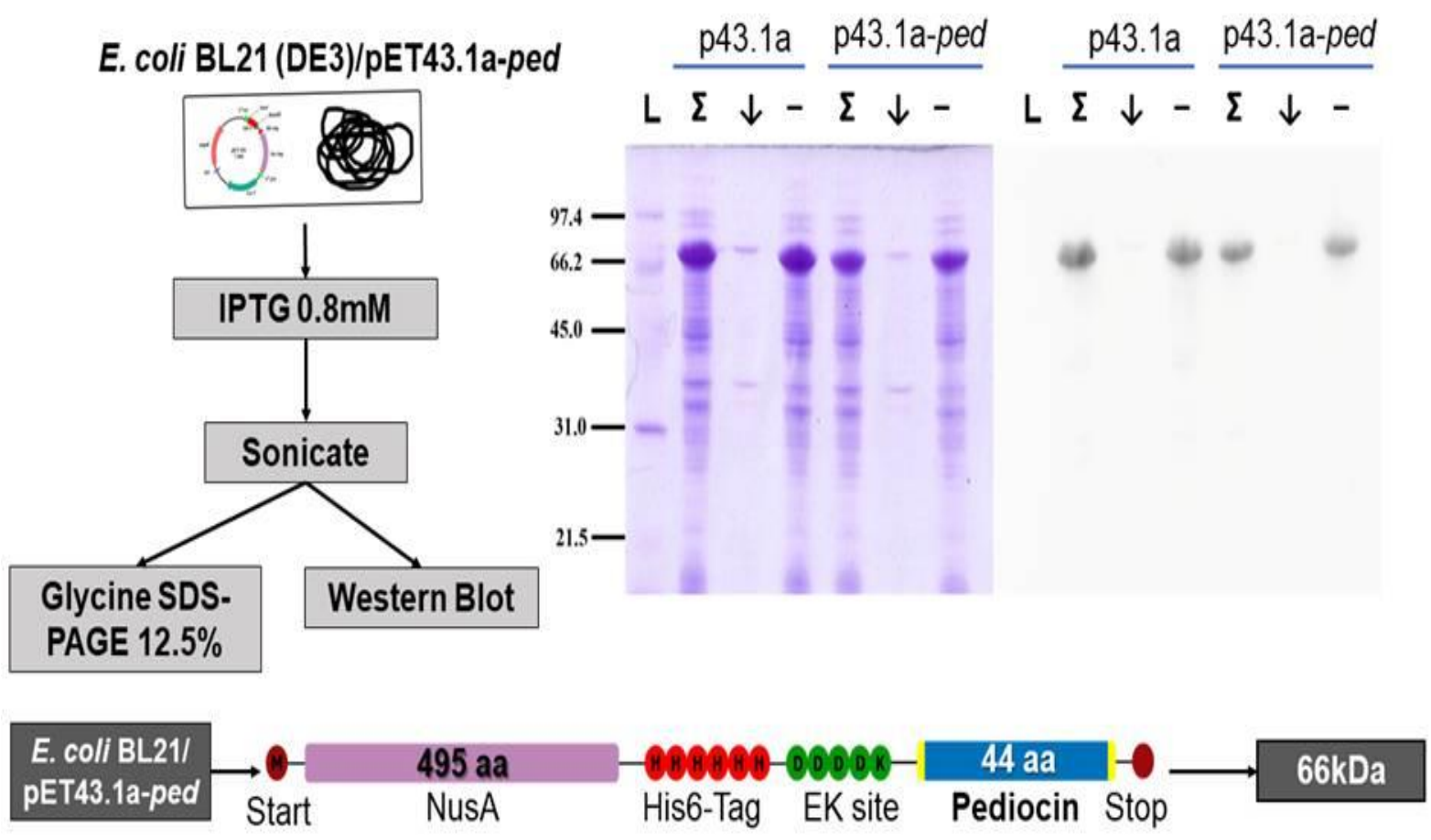

Fig. 2: Expression of recombinant pediocin in E. coli

L: protein ladder; p43.1a: extracted protein from E. coli/pET43.1a; p43.1a-ped: extracted protein from E. coli with carrying pediocin expressing vector / $p E T 43.1 a$-ped; $\Sigma$ : Total protein from the $E$. coli cells;

$\downarrow$ : Peletted protein from the E. coli cells. - : Soluble protein from the E. coli cells 
Collection of active recombinant pediocin- In order to collect active pediocin, NusA-his-pediocin was obtained from $E$. coli and was purified by nickel-NTA column. The results in Fig. 3 showed that we have successfully obtained NusA-His-pediocin after elution by $20 \%$ buffer $B$ (50 mM NaH${ }_{2} \mathrm{PO}_{4}, 300$ mM NaCl, 500 mM Imidazole pH
7.4). The eluted protein was in $46.92 \pm 3.12 \%$ purity and in $77.15 \pm 11.79 \%$ collected yield. Although we could collect NusA-his-pediocin in the fraction which was eluted by $30 \%$ buffer B with $95.3 \%$ of purity, the recovery was quite low (18.44 $\pm 5.53 \%)$.

Table 1: Purify of NusA-his-pediocin protein

\begin{tabular}{cccc}
\hline NusA-his-pediocin & $\begin{array}{c}\text { Total protein in } \\
\text { supernatant }\end{array}$ & $\begin{array}{c}\text { Eluted protein } \\
\mathbf{( 2 0 \%} \mathbf{B})\end{array}$ & $\begin{array}{c}\text { Eluted protein } \\
\text { (20\% B) }\end{array}$ \\
\hline Purity (\%) & $24.43 \pm 3.57$ & $46.92 \pm 3.12$ & $95.3 \%$ \\
Yield (mg) & $2.793 \pm 0.869$ & $2.155 \pm 0.549$ & $0.515 \pm 0.034$ \\
Recovery (\%) & 100 & $77.15 \pm 11.79$ & $18.44 \pm 5.53$ \\
\hline
\end{tabular}

The eluted NusA-his-Pediocin protein was then traeted by enterokinase enzyme in order to collect pediocin. The collected pediocin was applied to check its antibacterial activity by using $L$. monocytogene $\mathrm{MT}$ as indicator bacteria (Fig. 4). The results demonstrated that after treated by enterokinase we could release pediocin from the fusion NusA-his-pediocin protein and the free pediocin was about $4.6 \mathrm{kDa}$ with the antibacterial activity of L. monocytogene MT.
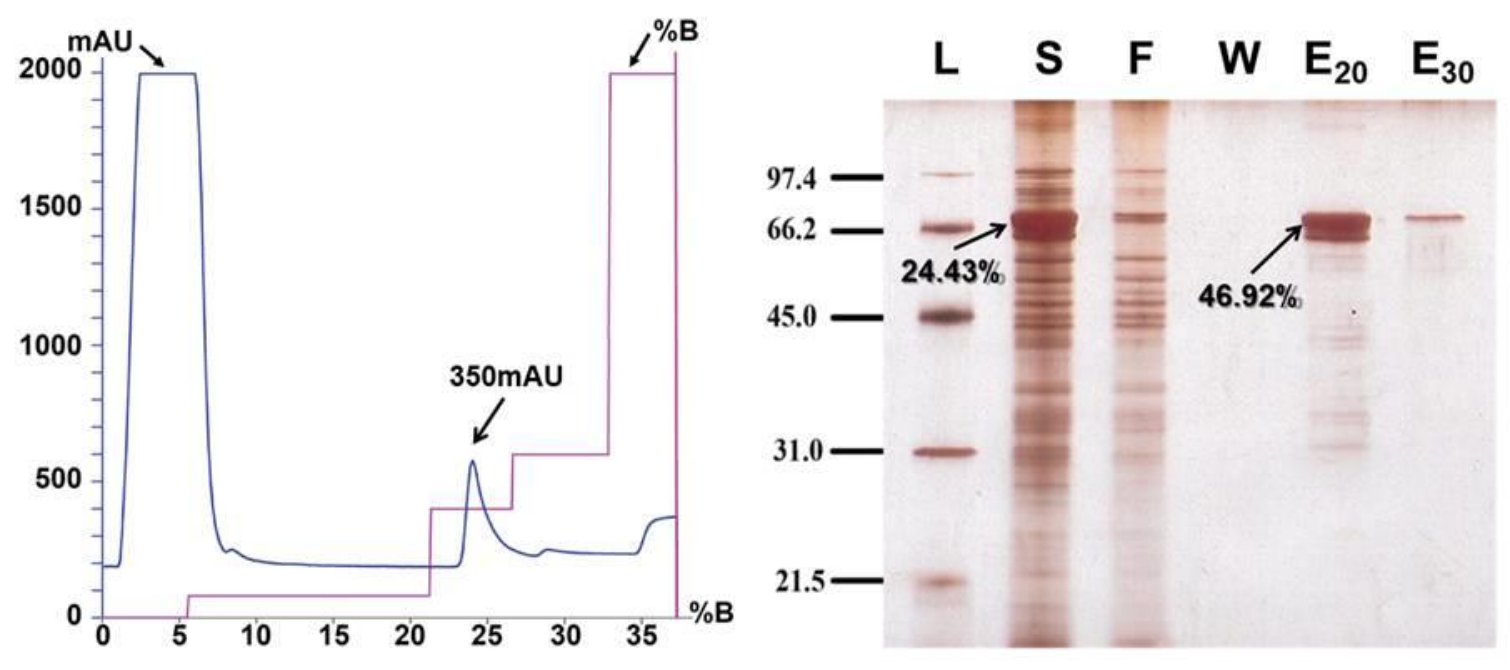

Fig. 3: Purification of NusA-his-pediocin

L: Protein ladder; S: Supernatant fraction from E. coli cell extract; F: Follow through fraction; W: Wash fraction;

$\mathbf{E}_{20}$ : elution fraction with $20 \%$ buffer $B$; $\mathbf{E}_{30}$ : elution fraction with $30 \%$ buffer $B$

\section{Analysis of the antimicrobial spectrum of recombinant} pediocin: Beside L. monocytogenes, antimicrobial spectrum of recombinant pediocin was also analyzed.

The results showed that recombinant pediocin has antibacterial activity against Gram positive bacteria such as L. monocytogene, L. inocua, Enterococcus faecalis.
Besides, the recombinant peptide pediocin also inhibited Gram negative bacteria such as Shigella boydii, Vibrio parahaemolyticus (Table 2). 
Table 2: Antimicrobial spectrum of recombinant pediocin

\begin{tabular}{|c|c|c|c|}
\hline S. No. & Indicator & Gram & Antibacterial activity \\
\hline 1 & Aeromonas caviae B168 & - & - \\
\hline 2 & Aeromonas dhakensis B77 & - & - \\
\hline 3 & Aeromonas hydrophila B56 & - & - \\
\hline 4 & Aeromonas hydrophila B66 & - & - \\
\hline 5 & Aeromonas veronii B141 & - & - \\
\hline 6 & Bacillus cereus & + & - \\
\hline 7 & Bacillus subtilis DHCT & + & - \\
\hline 8 & Clostridium botulinum E & + & - \\
\hline 9 & Clostridium botulinum D & + & - \\
\hline 10 & Clostridium perfringen 1 & + & - \\
\hline 11 & Enterococcus faecalis & + & + \\
\hline 12 & Escherichia coli 1/6 & - & - \\
\hline 13 & Escherichia coli DHCT & - & - \\
\hline 15 & Edwardsiella ictaluri LMG-Gly09M & - & - \\
\hline 16 & Edwardsiella tarda ATCC 15947 & - & - \\
\hline 17 & Enterobacter cloacae DHCT & - & - \\
\hline 18 & Enterotoxigenic Escherichia coli (ETEC) & - & - \\
\hline 19 & Listeria inocua & + & + \\
\hline 20 & Listeria monocytogen 364 & + & + \\
\hline 21 & Listeria monocytogene & + & + \\
\hline 22 & Listeria monocytogene MT & + & + \\
\hline 23 & Pseudomonas aeruginosa & - & - \\
\hline 24 & Pseudomonas aeruginosa $\mathrm{DHCT}$ & - & - \\
\hline 25 & Staphylococcus aureus 1 & + & - \\
\hline 26 & Staphylococcus aureus 2 & + & - \\
\hline 27 & Staphylococcus aureus B12 & + & - \\
\hline 28 & Staphylococcus aureus DHCT & + & - \\
\hline 29 & Salmonella dublin & - & - \\
\hline 30 & Salmonella enteritidis & - & - \\
\hline 31 & Salmonella sonei & - & - \\
\hline 32 & Salmonella typhi & - & - \\
\hline
\end{tabular}


33

34

35

36

37

38
Salmonella typhimurium

Shigella boydii

Shigella dysenteria

Shigella flexneri

Vibrioparahaemolyticus

Vibrio parahaemolyticus L2

\section{$-$}

- +

$-$

- +

\section{DISCUSSION}

Pediocin PA-1 is well known as an antimicrobial peptide with strong antibacterial activity against quite wide, broad of Gram positive pathogens such as $L$. monocytogenes, Staphylococcus aureus, Enterococcus faecalis. Pediocin thereby was reported as food preservatives to inhibit the growth of $L$. monocytogenes in some kind of meat and meat-related products such as Frankfurters, breast meat as well as fish product ${ }^{[17,18]}$. In this study, we successfully obtained recombinant pediocin from $E$. coli by using pET43a.1 vector. The recomniant pediocin was about $4.6 \mathrm{kDa}$ and showed its trong activity against not only on several gram positive bacteria as Enterococcus faecalis, $L$. innocua, $L$. monocytogen 364, L. monocytogene, L. monocytogene $M T$. Interestingly, the recombinant pediocin in this study also inhited two Gram negative bacteria Shigella boydii, Vibrio parahaemolyticus, which had not been reported before on bactibase database. The results suggested a deffirent mechanism of pediocin activity. The antibacterial activity of recombinant pediocin in this study is similar to pediocin from in Pediococcus pentosaceus K23-2 Shin et al. ${ }^{[19]}$ and Papagianni et al. ${ }^{[20]}$.

\section{CONCLUSIONS}

Pediocin is an antibacterial peptide which owns a strong potential on application for food and pharmaceutical industry. In this study, pediocin was introduced and expressed in $E$. coli by using PET43.a. The recombinant pediocin was successfully clevated from NusA-hispediocin fusion protein and showed its strong antibacterial activity. The results in this study enable a new door for further study on pediocin production and application.

\section{ACKNOWLEDGMENTS}

We thank Vietnam National University, Ho Chi Minh City for funded this study.

\section{CONTRIBUTION OF AUTHORS}

Research concept- Dr. Dang Thi Phuong Thao, Nguyen Hieu Nghia

Research design- Dr. Dang Thi Phuong Thao, Nguyen Hieu Nghia

Supervision- Dr. Dang Thi Phuong Thao

Materials- Dr. Dang Thi Phuong Thao

Data collection-Nguyen Hieu Nghia, Nguyen Thi Cam Nhung

Data analysis and Interpretation- Dr. Dang Thi Phuong Thao, Nguyen Hieu Nghia

Literature search- Dr. Dang Thi Phuong Thao, Nguyen Hieu Nghia

Writing article- Dr. Dang Thi Phuong Thao, Nguyen Hieu Nghia

Critical review- Dr. Dang Thi Phuong Thao

Article editing- Dr. Dang Thi Phuong Thao, Nguyen Hieu Nghia

Final approval- Dr. Dang Thi Phuong Thao

\section{REFERENCES}

[1] Henderson JT, CHOPKO AL, wassenaar V, Dick P. Purification and primary structure of pediocin PA-1 produced by Pediococcus acidilactici PAC-1.0. Arch. Biochem. Biophys., 1992; 295(1): 5-12.

[2] Rodriguez JM, Martinez MI, Kok J, Pediocin PA-1, a wide-spectrum bacteriocin from lactic acid bacteria. Critical Rev. Food Sci. Nutr., 2002; 42(2): 91-121.

[3] Papagianni M, Anastasiadou S. Pediocins the bacteriocins of Pediococci. Sources, production, properties and applications. Microb. Cell Factories, 2009; 8(1): 1-16.

[4] Yousef AE, Luchansky JB, Degnan AJ, Doyle MP, Behavior of Listeria monocytogenes in wiener exudates in the presence of Pediococcus acidilactici $\mathrm{H}$ or pediocin $\mathrm{AcH}$ during storage at 4 or 25 degrees C. Appl. Environ. Microbiol., 1991; 57(5): 1461-67. 
[5] Raccach M, Geshell D. The inhibition of Listeria monocytogenes in milk by pediococci. Food microbiol., 1993; 10(3): 181-86.

[6] MING X, WEBER GH, AYRES JW, SANDINE WE, Bacteriocins applied to food packaging materials to inhibit Listeria monocytogenes on meats. J. Food Sci., 1997; 62(2): 413-15.

[7] Rozum JJ, Maurer AJ, Microbiological quality of cooked chicken breasts containing commercially available shelf-life extenders. Poultry Sci., 1997; 76(6): 908-13.

[8] Szabo E, Cahill M, Nisin ALTATM 2341 inhibit the growth of Listeria monocytogenes on smoked salmon packaged under vacuum or $100 \% \mathrm{CO}_{2}$. Letters in Appl. Microbiol., 1999; 28(5): 373-77.

[9] Chen CM, Sebranek J, Dickson J, Mendonca A, Combining pediocin (ALTA 2341) with postpackaging thermal pasteurization for control of Listeria monocytogenes on frankfurters. J. Food Prot., 2004; 67(9): 1855-65.

[10]Montville T, Chen $Y$, Mechanistic action of pediocin and nisin: recent progress and unresolved questions. Applied microbiology and Biotechnol., 1998; 50(5): 511-19.

[11]Riley MA, Wertz JE. Bacteriocins: evolution, ecology, and application. Ann. Rev. Microbiol., 2002; 56(1): 117-37.

[12]Santiago-Silva $P$, Soares NF, Nobrega JE, Junior MA, Barbosa KB, et al. Antimicrobial efficiency of film incorporated with pediocin $\left(\right.$ ALTA $^{\circledast}$ 2351) on preservation of sliced ham. Food Control, 2009; 20(1): 85-89.

[13]Nieto-Lozano JC, Reguera-Useros Jl, Pelaez-Martinez MdC, Sacristan-Perez-Minayo, G, GutierrezFernandez AJ, et al. The effect of the pediocin PA-1 produced by Pediococcus acidilactici against Listeria monocytogenes and Clostridium perfringens in Spanish dry-fermented sausages and frankfurters. Food Control, 2010; 21(5): 679-85.
[14]Halami PM, Chandrashekar A. Heterologous expression, purification and refolding of an antilisterial peptide produced by Pediococcus acidilactici K7. Electronic J. Biotechnol., 2007; 10(4): 563-69. doi: $10.4067 /$ S0717-34582007000400009.

[15]Moon G-S, Pyun Y-R., Kim WJ, Expression purification of a fusion-typed pediocin PA-1 in Escherichia coli and recovery of biologically active pediocin PA-1. Int. J. Food microbiol., 2006; 108(1): 136-40. DOI: 10.1016/j.ijfoodmicro.2005.10.019.

[16]Bhunia AK, Johnson M, Ray B. Direct detection of an antimicrobial peptide of Pediococcus acidilactici in sodium dodecyl sulfate-polyacrylamide gel electrophoresis. J. Industrial Microbiol. Biotechnol., 1987; 2(5): 319-22.

[17]Fregeau G, Nancy L, et al. Three-dimensional structure of leucocin $A$ in trifluoroethanol and dodecylphosphocholine micelles: spatial location of residues critical for biological activity in type Ila bacteriocins from lactic acid bacteria. Biochem., 1997, 36(49): 15062-72. doi: 10.1021/bi971263h.

[18]Quadri, Luis EN, et al. Effect of amino acid substitutions on the activity of carnobacteriocin B2 overproduction of the antimicrobial peptide, its engineered variants, and its precursor in Escherichia coli. J. Biol. Chem., 1997; 272(6): 3384-88. doi: 10.1074/jbc.272.6.3384.

[19]Shin MS, et al. Isolation and partial characterization of a bacteriocin produced by Pediococcus pentosaceus $\mathrm{K} 23-2$ isolated from Kimchi. J. App. Microiol., 2008; 105(2): 331-39. doi: 10.1111/j.13652672.2008.03770.x.

[20]Papagianni M, Anastasiadou S. Pediocins: The bacteriocins of Pediococci. Sources, production, properties and applications. Microb. Cell Factories, 2009; 8(1): 3-9. doi: 10.1186/1475-2859-8-3.

\section{Open Access Policy:}

Authors/Contributors are responsible for originality, contents, correct references, and ethical issues. SSR-IIJLS publishes all articles under Creative Commons Attribution- Non-Commercial 4.0 International License (CC BY-NC). https://creativecommons.org/licenses/by-nc/4.0/legalcode (c) (1) (8) 